\title{
Dopamine Deficiency Contributes to Early Visual Dysfunction in a Rodent Model of Type 1 Diabetes
}

\author{
Moe H. Aung, ${ }^{1,2,5}$ Han na Park, ${ }^{2,5}$ Moon K. Han, ${ }^{2,5}$ Tracy S. Obertone, ${ }^{2,5}$ Jane Abey, ${ }^{2}$ Fazila Aseem, ${ }^{2}$ Peter M. Thule, $, 3,6$ \\ P. Michael Iuvone, ${ }^{1,2,4}$ and Machelle T. Pardue ${ }^{1,2,5}$ \\ ${ }^{1}$ Department of Neuroscience, ${ }^{2}$ Department of Ophthalmology, ${ }^{3}$ Department of Endocrinology, and ${ }^{4}$ Department of Pharmacology, Emory University, \\ Atlanta, Georgia 30322, and ${ }^{5}$ Rehab R\&D Center of Excellence and ${ }^{\circ}$ Biomedical Laboratory Research and Development, Atlanta VA Medical Center, Atlanta, \\ Georgia 30033
}

Dopamine (DA) functions as an essential neuromodulator in the brain and retina such that disruptions in the dopaminergic system are associated with common neurologic disorders such as Parkinson's disease. Although a reduction in DA content has been observed in diabetes, its effects in the development of diabetes-induced neuropathy remains unknown. Because the retina is rich in DA and has a well known diabetes-induced pathology (diabetic retinopathy or DR), this study was designed to examine the role of retinal DA deficiency in early visual defects in DR. Using rodent models of type 1 diabetes mellitus, we investigated whether diabetes caused a reduction in retinal DA content in both rats and mice and determined whether restoring DA levels or activating specific DA receptor pathways could improve visual function (evaluated with optokinetic tracking response) of diabetic mice, potentially via improvement of retinal function (assessed with electroretinography). We found that diabetes significantly reduced DA levels by 4 weeks in rats and by 5 weeks in mice, coincident with the initial detection of visual deficits. Treatment with L-DOPA, a DA precursor, improved overall retinal and visual functions in diabetic mice and acute treatment with DA D1 or D4 receptor agonists improved spatial frequency threshold or contrast sensitivity, respectively. Together, our results indicate that retinal DA deficiency is an underlying mechanism for early, diabetes-induced visual dysfunction and suggest that therapies targeting the retinal dopaminergic system may be beneficial in early-stage DR.

Key words: Diabetic retinopathy; Dopamine; Visual function

\section{Introduction}

The catecholamine dopamine (DA) is a crucial neurotransmitter in both the brain and retina. DA is synthesized from tyrosine via L-3,4-dihydroxyphenylalanine (L-DOPA), with the enzyme tyrosine hydroxylase $(\mathrm{TH})$ being the rate-limiting step (Björklund and Dunnett, 2007; Fernstrom and Fernstrom, 2007). In addition to regulating a host of neural processes that include motor, cognition, and retinal function (Witkovsky, 2004), retinal DA directly modulates multiple aspects of light-adapted vision through activation of selective receptors and retinal pathways (Jackson et al., 2012). Although studies have investigated the role of DA malfunction on visual deficits in multiple disorders (e.g., Parkinson's

Received Aug. 13, 2013; revised Nov. 22, 2013; accepted Nov. 26, 2013.

Author contributions: M.H.A., P.T., P.M.I., and M.P. designed research;M.H.A., H.P., T.S.O., M.K.H., J.A., and F.A. performed research; M.H.A., H.P., T.S.O., J.A., F.A., P.M.I., and M.P. analyzed data; M.H.A., H.P.,P.T., P.M.I., and M.P. wrote the paper.

This work was supported by the National Institutes of Health (NIH Grants P30 EY006360 and R01 EY004864 to P.M.I. and National Institute of Diabetes and Digestive and Kidney Diseases Grant R01 DK07601-01 to P.M.T.); the Department of Veterans Affairs (Rehabilitation R\&D Service Merit Award and Research Career Scientist Award to M.T.P. and Biological Laboratory R\&D Service Merit Award to P.M.T.); Research to Prevent Blindness (Departmental Award); the Juvenile Diabetes Research Foundation (Research Grant and Innovative Award to P.M.T.); and the Children's Healthcare of Atlanta Research Center (Award to P.M.T.).

Correspondence should be addressed to Machelle T. Pardue, Research Service (1510ph), Atlanta Veterans Affairs Medical Center, 1670 Clairmont Road, Decatur, GA 30033. E-mail: mpardue@emory.edu.

DOI:10.1523/JNEUROSCI.3483-13.2014

Copyright $\odot 2014$ the authors $\quad 0270-6474 / 14 / 340726-11 \$ 15.00 / 0$ disease and schizophrenia; Brandies and Yehuda, 2008), its potential contribution to the pathogenesis of diabetic retinopathy (DR), a leading cause of vision impairment in working-age adults (King et al., 1998; Congdon et al., 2003; Klein, 2007), remains unclear.

Historically, DR has been primarily considered a vascular disorder due to its association with late-stage structural defects of the retinal vasculature (Cai and Boulton, 2002). Typically, after decades of hyperglycemia, increasing retinal vascular occlusions produce ischemia that drives an aggressive neovascularization response (also known as proliferative DR) and/or macular edema (Frank, 2004). These late-stage vascular lesions are the direct antecedents of severe vision loss associated with DR. Although clinical research has emphasized retinal vascular changes in diabetes, retinal neuronal dysfunction that predates clinically detectable vascular lesions is increasingly recognized (Barber, 2003; Antonetti et al., 2006). Electroretinogram (ERG) responses are consistently diminished and delayed in diabetic patients without vascular pathologies (Ghirlanda et al., 1997; Shirao and Kawasaki, 1998). Moreover, several neuronal cell types are less abundant in diabetic retinas compared with age-matched control retinas (Abu-El-Asrar et al., 2004; Martin et al., 2004; Abu ElAsrar et al., 2007; Fletcher et al., 2007; Kern and Barber, 2008). In addition, diabetic patients with angiographically normal retinas experience subtle visual dysfunction, including abnormal color 
vision and decreased contrast sensitivity (Jackson and Barber, 2010). Similar early visual dysfunctions have been consistently replicated in rodent models of diabetes (Kirwin et al., 2011; Akimov and Rentería, 2012; Muir et al., 2012; Aung et al., 2013). Although most reports emphasize the potential role of retinal defects as a contributing factor for the visual deficits, little is known about the underlying mediator(s).

Interestingly, disruption in the retinal dopaminergic system has also been observed in diabetes. DA levels are reduced in diabetic rat retinas at 1 month after diabetic induction (Nishimura and Kuriyama, 1985). Furthermore, loss of TH-positive retinal neurons has been reported after 6 months of diabetes (Gastinger et al., 2006). Because retinal DA modulates ERG and visual function (Herrmann et al., 2011; Jackson et al., 2012), we hypothesized that diabetes causes reduced retinal DA content, which then leads to the visual dysfunction observed in early-stage DR. To test this hypothesis, we evaluated the effects of diabetes on retinal DA levels in our diabetic rodent models. We then determined whether chronic restoration of DA levels or acute activation of specific DA receptor pathways ameliorated early diabetesassociated visual deficits.

\section{Materials and Methods}

Animals and experimental design. All animals were housed in ventilated cages on a $12 \mathrm{~h}$ light-dark cycle (light onset at 6:00 A.M.) with food and water provided ad libitum. All procedures were approved by the Atlanta VA Institutional Animal Care and Use Committee and conformed to the ARVO Statement for the Use of Animals in Ophthalmic and Vision Research.

Comparison of dopamine levels between control and diabetic animals. Diabetes was induced in 2-month-old male Long-Evans rats (Charles River Laboratories) with a single intravenous injection of streptozotocin (STZ: $100 \mathrm{mg} / \mathrm{kg}$; Sigma-Aldrich) dissolved in citrate buffer $/ 50 \%$ glucose solution (8:1 ratio), serving as a model for type 1 diabetes mellitus (DM). Age-matched male control (CTRL) rats were injected with citrate buffer/ $50 \%$ glucose solution alone. Diabetes was defined as two successive daily blood glucose levels $>250 \mathrm{mg} / \mathrm{dL}$ (determined with hand-held blood glucose meter from tail-prick blood; Clee and Attie, 2007), which occurred routinely 2-3 d after STZ injection. Weight and blood glucose levels of the animals were monitored twice a week for the entire duration of the experiment. When DM rats were found to be losing weight, they were treated with a pellet of sustained-release subcutaneous insulin (Linplant; Linshin Canada) at a dose adequate to prevent weight loss but insufficient to control hyperglycemia $(13 \pm 3 \mathrm{mg} /$ pellet with a release rate of $\sim 2 \mathrm{U} / \mathrm{d}$; Thulé et al., 2006). Rats were maintained for either 4 or 12 weeks ( $n=6$ per treatment group at each time point).

To assess the effects of diabetes on retinal DA content in mouse, 1.5month-old male CD-1 albino mice (Charles River Laboratories) were injected intraperitoneally daily for 5 consecutive days with either vehicle (citrate buffer $/ 50 \%$ glucose solution in $8: 1$ ratio) or STZ $(50 \mathrm{mg} / \mathrm{kg}$ ). Diabetes was defined similar to the rat experiment described above (successive blood glucose levels of $>250 \mathrm{mg} / \mathrm{dL}$ ). Weight and blood glucose levels of the animals were also monitored twice a week. DM mice that lost $>10 \%$ body weight were given an intraperitoneal injection of $1 \mathrm{U}$ of insulin (NovoLog; Novo Nordisk) diluted 1:10 in Ringer's solution to prevent catabolic weight loss. Both CTRL and DM mice $(n=8$ per treatment group) were then followed for 5 weeks.

All animals, both rats and mice, were killed between 4 and $6 \mathrm{~h}$ after light onset to prevent diurnal differences in DA and 3,4dihydroxyphenyl-acetic acid (DOPAC, a major metabolite of DA that is catalyzed by the enzyme monoamine oxidase) levels (Nir et al., 2000; Witkovsky, 2004). Retinas were collected into amber tubes, stored at $-80^{\circ} \mathrm{C}$, and analyzed for DA and DOPAC levels using HPLC with coulometric detection, as described in Dopamine and DOPAC analysis section, below.

Chronic treatment with L-DOPA. In this experiment, we used 2-month-old pigmented mice on C57 background (mixture of males and
Table 1. Sequences of the primers used in RT-PCR reactions for genes of interest

\begin{tabular}{|c|c|c|}
\hline $\begin{array}{l}\text { Gene of } \\
\text { interest }\end{array}$ & Primer sequence & \\
\hline \multirow[t]{2}{*}{ Th } & Forward & 5'-TGCCCGTGATTTTCTGGCCAGT-3' \\
\hline & Reverse & 5'-TGTCCTGGGAGAACTGGGCAAA-3' \\
\hline \multirow[t]{2}{*}{$\operatorname{Drd} 1$} & Forward & 5'-CAGCCTTCATCCTGATTAGCGTAG-3' \\
\hline & Reverse & 5'-CTTATGAGGGAGGATGAAATGGCG-3' \\
\hline \multirow[t]{2}{*}{$\operatorname{Drd4}$} & Forward & 5' - TCTTTGTCTACTCCGAGGTCCAG-3' \\
\hline & Reverse & 5'-TCACGGCCACGAACCTGTCCA-3' \\
\hline \multirow[t]{2}{*}{185} & Forward & 5'-GTTGGTTTTCGGAACTGAGGC-3' \\
\hline & Reverse & 5'-GTCGGCATCGTTTATGGTCG-3' \\
\hline
\end{tabular}

females) with tyrosine hydroxylase (Th) and consequently with DA selectively deleted in the retina. As described previously (Jackson et al., 2012), these mice were created by crossing Chx10-Cre recombinaseexpressing mice with mice expressing floxed Th gene. Wild-type mice ( $T h^{\text {loxP/loxp }}$, herein referred to as WT) and conditional Th knock-out (Chx10-Cre: $T h^{\text {loxP/loxP }}$, herein referred to as $\left.\mathrm{rTHKO}\right)$ mice were rendered diabetic, with repeated STZ (50 mg/kg). DM mice that lost $>10 \%$ body weight were given an intraperitoneal injection of $1 \mathrm{U}$ of insulin (NovoLog; Novo Nordisk) diluted 1:10 in Ringer's solution to prevent cachexia. CTRL mice were injected with citrate buffer $/ 50 \%$ glucose solution. CTRL and DM mice of both WT and rTHKO genotypes then received daily intraperitoneal injections of either L-DOPA $(10 \mathrm{mg} / \mathrm{kg}$; Sigma-Aldrich) dissolved in $0.1 \%$ ascorbic acid in saline solution or vehicle alone (Veh) between 4 and $8 \mathrm{~h}$ after light onset. The treatment injections (vehicle and L-DOPA) were initiated when majority of the DM animals had elevated blood glucose levels of $>250 \mathrm{mg} / \mathrm{dL}$. The sample size for each treatment group is shown in the figure legends or captions. L-DOPA was made fresh daily at a concentration of $1 \mathrm{mg} / \mathrm{ml}$. Mice were maintained for 6 weeks, with their visual function assessed weekly and retinal function assessed with ERG at the 5-week time point. All functional tests were conducted $30 \mathrm{~min}$ to $1 \mathrm{~h}$ after L-DOPA or vehicle injection.

Acute treatment with selective dopamine receptor agonists. Diabetes was induced in 2-month-old pigmented male WT mice $(n=7)$ with repeated STZ $(50 \mathrm{mg} / \mathrm{kg})$. Pigmented mice were used in this experiment due to lack of OKT responses from albino mice (Puk et al., 2008). After 8 weeks of diabetes, all mice were successively injected intraperitoneally once with the following: (1) D1 receptor agonist SKF38393 (1 mg/kg; Tocris Biosciences), (2) vehicle ( $0.9 \% \mathrm{NaCl}$ solution), and (3) D4 receptor agonist PD168077 (1 mg/kg; Tocris Biosciences; Jackson et al., 2012). There was 1-2 d interval between each treatment to clear the previous drug effects, which should be adequate because the half-lives of SKF38393 and PD168077 are 1-3 h (Jackson et al., 1988; Moreland et al., 2005). Spatial frequency thresholds and contrast sensitivity levels were measured 30 min after each treatment.

Visual psychophysical testing. Visual function of each animal was tested using the virtual optokinetic system (OptoMotry system; CerebralMechanics), as described previously (Douglas et al., 2005; Aung et al., 2013). Briefly, the animal was placed on a platform surrounded by four computer monitors that displayed vertical sine wave gratings rotating at 12 degrees/s. A video camera positioned above the animal allowed an observer to determine the presence or absence of visual tracking. Tracking was defined as slow head movements in the same direction and speed as the rotating gratings. For spatial frequency threshold assessment, the grating started at a spatial frequency of 0.042 cycles/degree with $100 \%$ contrast and increased in a staircase paradigm until the response threshold was crossed three times. Similarly, contrast sensitivity was determined by reducing the contrast between the black and white gradients from $100 \%$ in a staircase paradigm until animal head-tracking movements were no longer observed. Contrast sensitivity was measured at the spatial frequency of 0.064 cycles/degree for all animals in the study. This was the spatial frequency that elicited the maximal sensitivity from both rats and mice at baseline (data not shown). The contrast sensitivity was calculated as a reciprocal of the Michelson contrast from the screen's luminance [i.e., (maximum + minimum) $/($ maximum - 
Table 2. Average weight and blood glucose (BG) levels of the experimental groups ( \pm SEM) used for this project

\begin{tabular}{|c|c|c|c|c|c|c|}
\hline \multirow[b]{2}{*}{ Species } & \multirow[b]{2}{*}{ Time point (wk) } & \multirow[b]{2}{*}{ Treatment group } & \multicolumn{2}{|l|}{ Baseline } & \multicolumn{2}{|l|}{ End of study } \\
\hline & & & Weight (g) & $\mathrm{BG}(\mathrm{mg} / \mathrm{dl})$ & Weight (g) & $\mathrm{BG}(\mathrm{mg} / \mathrm{dl})$ \\
\hline \multirow[t]{4}{*}{ Rat } & \multirow[t]{2}{*}{4} & CTRL & $209 \pm 4.5$ & $147 \pm 4$ & $382 \pm 11.2$ & $141 \pm 8$ \\
\hline & & DM & $212 \pm 6.6$ & $149 \pm 3$ & $294 \pm 7.5$ & $547 \pm 15$ \\
\hline & \multirow[t]{2}{*}{12} & CTRL & $334 \pm 15.0$ & $129 \pm 6$ & $588 \pm 23.5$ & $124 \pm 7$ \\
\hline & & DM & $325 \pm 12.3$ & $125 \pm 2$ & $380 \pm 15.6$ & $546 \pm 19$ \\
\hline \multirow[t]{2}{*}{ Mouse } & \multirow[t]{2}{*}{5} & CTRL & $26.3 \pm 0.5$ & $187 \pm 10$ & $37.8 \pm 1.1$ & $138 \pm 6$ \\
\hline & & DM & $26.6 \pm 0.6$ & $186 \pm 9$ & $30.9 \pm 0.7$ & $508 \pm 31$ \\
\hline \multirow[t]{6}{*}{ Mouse } & \multirow[t]{6}{*}{6} & CTRL WT + Veh & $21.7 \pm 2.6$ & $165 \pm 5$ & $22.6 \pm 2.3$ & $168 \pm 11$ \\
\hline & & CTRL WT + L-DOPA & $20.0 \pm 2.3$ & $147 \pm 8$ & $20.8 \pm 2.2$ & $139 \pm 19$ \\
\hline & & DM WT + Veh & $23.3 \pm 0.8$ & $165 \pm 10$ & $23.0 \pm 0.7$ & $349 \pm 29$ \\
\hline & & DMWT + L-DOPA & $21.9 \pm 1.0$ & $187 \pm 11$ & $19.1 \pm 0.9$ & $504 \pm 29$ \\
\hline & & DM rTHKO + Veh & $22.2 \pm 1.1$ & $185 \pm 10$ & $21.2 \pm 1.0$ & $426 \pm 43$ \\
\hline & & DM rTHKO + L-DOPA & $23.4 \pm 1.5$ & $182 \pm 14$ & $20.9 \pm 1.2$ & $431 \pm 35$ \\
\hline Mouse & 8 & DM & $32.9 \pm 0.8$ & $187 \pm 7$ & $26.7 \pm 0.6$ & $437 \pm 18$ \\
\hline
\end{tabular}

A

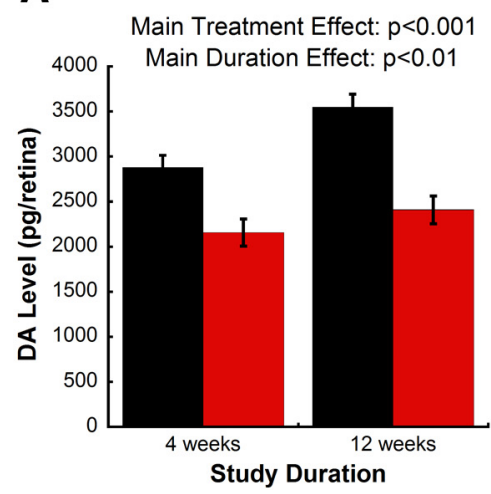

B

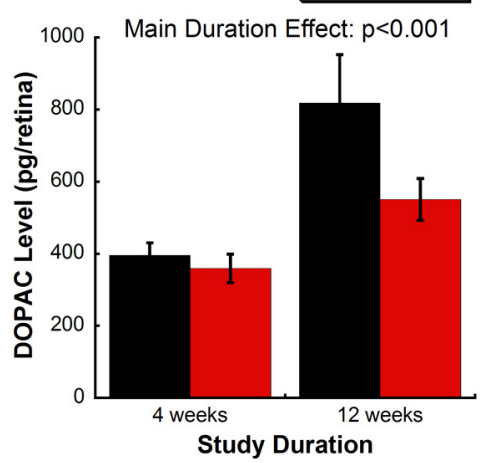

C

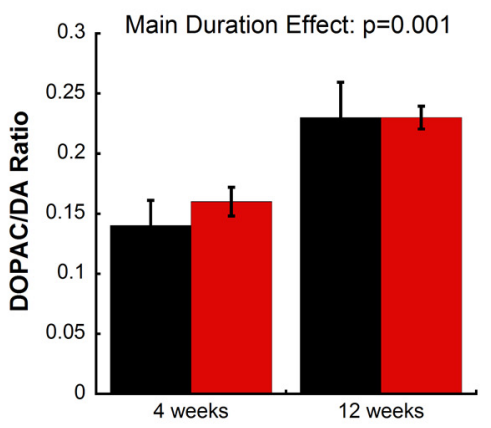

Study Duration

Figure 1. Diabetes results in reduced retinal DA content. $A, 0$ verall, DM rats exhibited significantly reduced DA levels compared with CTRL animals (main treatment effect: $p<0.001)$. There was also a significant age-dependent increase in DA levels of all animals (main duration effect: $p<0.01$ ). $\boldsymbol{B}$, Regardless of diabetes status, rats had significantly higher DOPAC levels at the 12-week time point than at the 4-week time point (main duration effect: $p<0.001$ ). DM animals showed a trend toward lower DOPAC levels compared with CTRL animals at the 12-week time point. C, Metabolism of DA to DOPAC did not differ between CTRL and DM animals. No significant change in the DOPAC/DA ratio was detected due to diabetes in Long-Evans rats. However, there was an increase in dopamine metabolism due to age (main duration effect: $p=0.001$ ).

minimum)], as described previously (Prusky et al., 2006). All OKTs were done $30 \mathrm{~min}$ to $1 \mathrm{~h}$ after any treatment given (vehicle, L-DOPA, or DA receptor agonists), which usually occurred between 5 and $10 \mathrm{~h}$ after light onset.

Retinal function test. To assess retinal function with ERG, we performed dark-adapted ERG luminance series and light-adapted flicker exposure. All ERGs were done $30 \mathrm{~min}$ to $1 \mathrm{~h}$ after any treatment given (vehicle or L-DOPA), which usually occurred between 5 and $10 \mathrm{~h}$ after light onset. In brief, mice were dark adapted overnight and then prepared under dim red illumination. After being anesthetized with ketamine $(80 \mathrm{mg} / \mathrm{kg})$ and xylazine $(16 \mathrm{mg} / \mathrm{kg})$, we dilated the pupils ( $1 \%$ tropicamide) and numbed the corneal surface $(0.5 \%$ tetracaine $\mathrm{HCl}$ ). Using a gold loop electrode, darkadapted responses were recorded with a signal averaging system (UTAS BigShot; LKC Technologies) to flash stimuli presented in order of increasing luminance (scotopic: -3.0 to 2.1

$\log \cdot \mathrm{cd} \cdot \mathrm{s} / \mathrm{m}^{2}$ ), so that rod-dominated and mixed rods and cones responses could be isolated.

To further isolate the cone pathway function, mice were then exposed to a steady background adapting field $\left(30 \mathrm{~cd} / \mathrm{m}^{2}\right)$ for $10 \mathrm{~min}$ to saturate the rod photoreceptors. After the light-adaptation period,
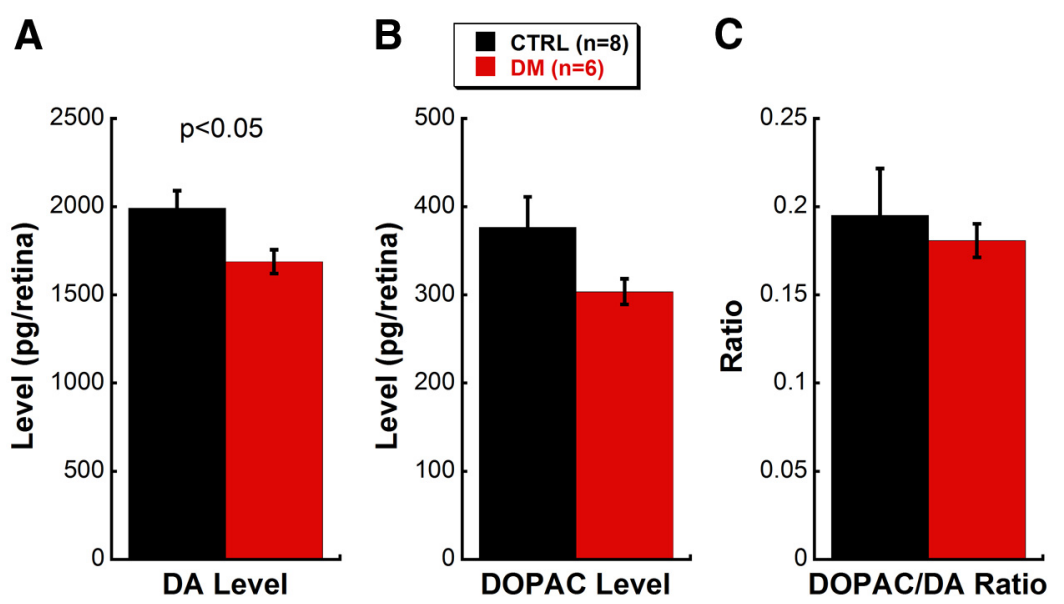

Figure 2. Diabetes lowers retinal DA levels in STZ-induced DM mice. $\boldsymbol{A}$, At the 5 -week time point, DM mice had significantly reduced retinal DA contents compared with the CTRL mice $(p=0.039)$. $\boldsymbol{B}, \boldsymbol{C}, \mathrm{A}$ slight trend for decreased DOPAC levels or DOPAC/DA ratios due to diabetes was observed.

animals were presented with $2.0 \mathrm{log} \cdot \mathrm{cd} \cdot \mathrm{s} / \mathrm{m}^{2}$ flicker stimuli at $6 \mathrm{~Hz}$ in the presence of the background light. Responses were recorded using the same signal averaging system (UTAS BigShot; LKC Technologies). After testing, rats received yohimbine $(2.1 \mathrm{mg} / \mathrm{kg})$ to reverse the effects of xylazine and to prevent corneal ulcers (Turner and Albassam, 2005). 

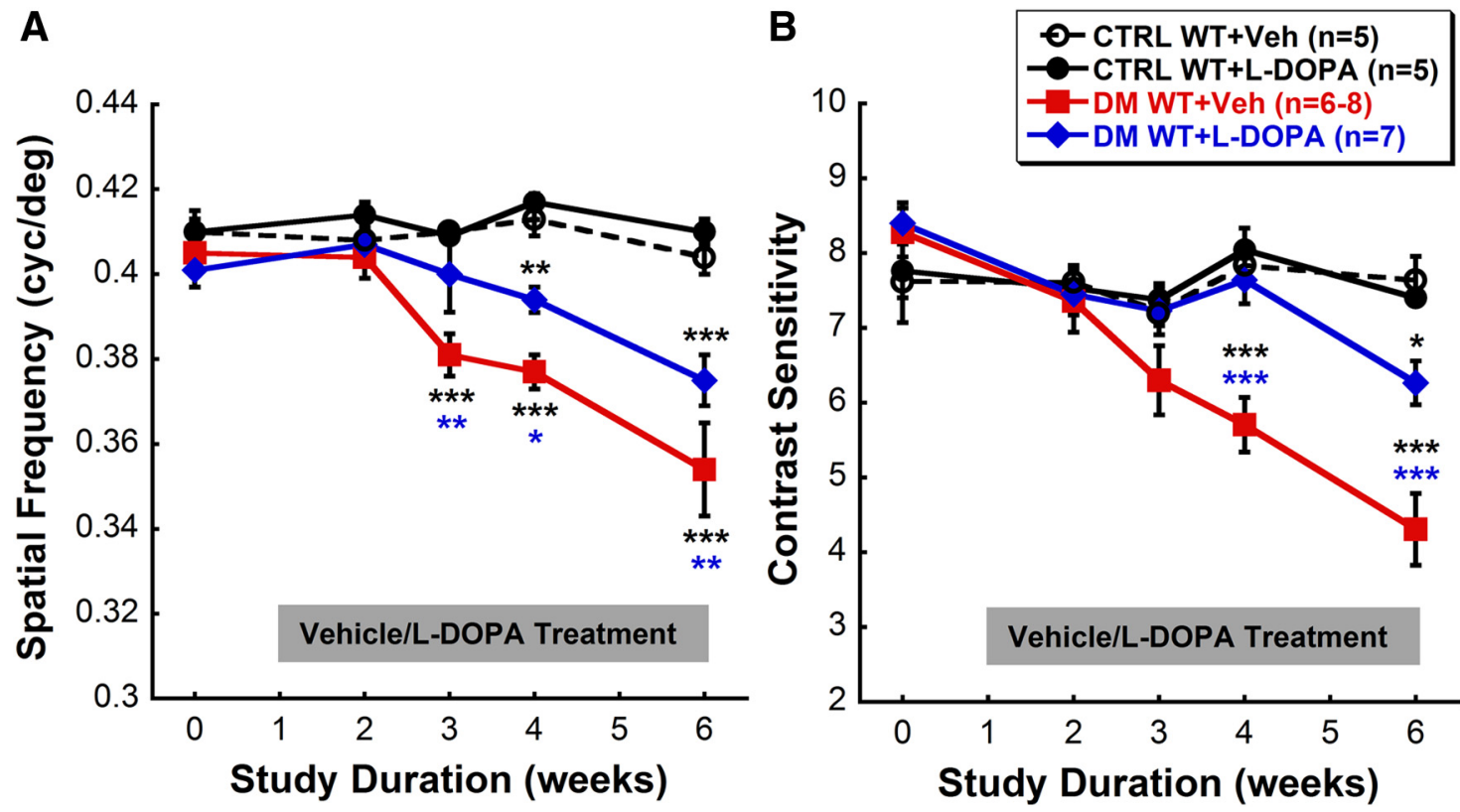

Figure 3. Chronic L-DOPA treatment delays early diabetes-induced visual dysfunction. $A, D M W T+$ Veh mice showed significant reductions in spatial frequency threshold from CTRL animals as early as 3 weeks after STZ (post hoc comparison, $p<0.001$ ). In contrast, the visual deficits appeared in DM WT + L-DOPA mice starting at 4 weeks after STZ (post hoc comparison, $p<0.01$ ) with a slower and less severe progression. $B$, Contrast sensitivities were also significantly reduced in DM WT + Veh mice ( posthoc comparison, $p<0.001$ ) at 4 weeks after STZ, whereas DM WT $+\mathrm{L}-\mathrm{DOPA}$ mice only exhibited a slight decrease in sensitivity at 6 weeks after STZ (post hoc comparison, $p<0.05$ ). The color of the asterisk indicates the treatment group for which significance was reached, with the exception of the black asterisk, which refers to both CTRL WT + Veh and CTRL WT + L-DOPA groups. Note that the $y$-axis does not start at zero; it is modified to more clearly show the differences between treatment groups.

Data were analyzed offline. For the dark-adapted ERG responses, amplitudes and implicit times were measured for both a- and b-waves. For the light-adapted ERG responses, amplitudes of the flicker responses were measured from the trough of the signal after the flash onset to the peak. Implicit times were determined from flash onset to the peak.

Dopamine and DOPAC analysis. DA and DOPAC levels were assessed by ion-pair reverse-phase HPLC with coulometric detection, as described previously (Pozdeyev et al., 2008). Frozen retinas were homogenized in $0.2 \mathrm{~N}$ $\mathrm{HClO}_{4}$ solution containing $0.01 \%$ sodium meta-bisulfate and $25 \mathrm{ng} / \mathrm{ml} 3,4-$ dihydroxybenzylamine hydrobromide as an internal standard and centrifuged. Each supernatant fraction was separated on an Ultrasphere ODS 5 $\mu \mathrm{m} 250 \times 4.6 \mathrm{~mm}$ column (Beckman Coulter) with a mobile phase containing $0.1 \mathrm{M}$ sodium phosphate, $0.1 \mathrm{~mm}$ EDTA, $0.35 \mathrm{~mm}$ sodium octylsulfate, and $6 \%$ acetonitrile, $\mathrm{pH}$ 2.7. The DA and DOPAC signals from each sample were quantified using a detection curve established by standards ranging from 2 to $20 \mathrm{ng} / \mathrm{ml}$. Levels of DA and DOPAC were then presented as picograms of DA or DOPAC per retina.

$R T-P C R$ analysis. Single retinas were placed in a $1.5 \mathrm{ml}$ tube and homogenized with $50 \mu \mathrm{l}$ of zirconium oxide beads $(0.5 \mathrm{~mm})$ and $100 \mu \mathrm{l}$ of TRIzol in a Bullet Blender (Next Advance) for 3-6 min. Chloroform (20 $\mu \mathrm{lof} \mathrm{CHCl}_{4}$ ) was added to each sample, shaken, and then centrifuged for $15 \mathrm{~min}$ at $4^{\circ} \mathrm{C}$. The RNA-containing aqueous phase was then transferred to a fresh tube and cleaned using an RNA purification kit (RNeasy Mini; Qiagen) according to the manufacturer's instructions using a final elution volume of $30 \mu \mathrm{l}$. For each sample, $1 \mu \mathrm{g}$ of RNA was reverse transcribed to cDNA with the QuantiTect kit (Qiagen). The resulting cDNA was diluted 1:20 with water and $1.5 \mu \mathrm{l}$ was used in each quantitative real-time PCR (RT-PCR). RT-PCRs were performed in a $10 \mu$ l volume with SYBR green $2 \times$ Master Mix (Bio-Rad) in a RealPlex 4 cycler (Eppendorf North America). The primer sequences are listed in Table 1. Conditions for the RT-PCRs were $95^{\circ} \mathrm{C}, 3 \mathrm{~min}$; 40 cycles of $94^{\circ} \mathrm{C}, 30 \mathrm{~s}$ denaturation; $65^{\circ} \mathrm{C}, 30 \mathrm{~s}$ annealing; $72^{\circ} \mathrm{C}, 30 \mathrm{~s}$ extension; $72^{\circ} \mathrm{C}, 7 \mathrm{~min}$, with fluorescence recorded at the end of each $72^{\circ} \mathrm{C}$ extension. Melt curve analysis conditions were heating from 55 to $95^{\circ} \mathrm{C}$ in $0.5^{\circ} \mathrm{C}$ increments, $15 \mathrm{~s}$ per increment, with fluorescence recorded at each increment. The cycle threshold $(\mathrm{Ct})$ value of each reaction was determined as the cycle number in which the log increasing fluorescence intersects the threshold level as determined by the software. Three replicates were performed for each cDNA sample-primer pair combination and the average $\mathrm{Ct}$ was calculated. Using $18 \mathrm{~S}$ as the internal control, the expression of each gene of interest was calculated from the average PCR cycle thresholds using the $2^{-\Delta \mathrm{Ct}}$ method (Livak and Schmittgen, 2001; Schmittgen and Livak, 2008). The fold change of the gene expression was further calculated by taking the ratio of the $2^{-\Delta \mathrm{Ct}}$ average of the treatment group over the $2^{-\Delta \mathrm{Ct}}$ average of the control group.

Statistical analysis. Statistical analysis was performed using commercial statistical software (SigmaStat 3.5; Aspire Software International). Two-way repeated-measures ANOVAs were used to compare DA and DOPAC levels and visual function of treatment groups across time points after STZ injection. For ERG analysis, one-way ANOVAs were used to compare between treatment groups. Due to a failed normality test for the analysis of the efficacy of systemic L-DOPA treatment in increasing retinal DA content, one-way ANOVAs on rank were used instead to compare between treatment groups. Post hoc multiple comparisons for all ANOVA tests were performed when appropriate with $p$-value corrected with the rough false discovery rate method (RFDR), calculated as $\mathrm{p}^{*}$ (\#tests +1$) /\left(2^{*}\right.$ (\#tests). For DA and DOPAC analysis in mice, Student's $t$ test was performed to determine whether retinal DA content differed between the experimental groups. For RT-PCR analysis, multiple Student's $t$ tests were used to determine whether the expressions of the treatment groups were different from the control group, with the critical levels corrected with RFDR method. All analyses were performed with a priori significance set at $\alpha<0.05\left({ }^{\star} p<0.05 ;{ }^{* *} p<0.01 ;{ }^{* * *} p<0.001\right)$. All data are presented as mean \pm SEM.

\section{Results}

Diabetes resulted in significant reduction in retinal dopamine level

To assess the effects of diabetes on retinal DA levels, we rendered rats diabetic for either 4 or 12 weeks and compared their retinal DA levels with age-matched CTRL rats. All rats receiving STZ became hyperglycemic with reduced weight compared with 
citrate-buffer-treated rats (Table 2). Overall, DA levels were significantly decreased in DM rats compared with CTRL rats (main treatment effect: $F_{(1,17)}=$ 38.233, $p<0.001$; Fig. $1 A$ ). DA levels also increased as the animals aged, regardless of diabetes status (main duration effect: $F_{(1,17)}=9.407, p=0.007$; Fig. $\left.1 A\right)$. Moreover, DA reduction worsened from $\sim 25 \%$ at the 4 -week time point to $32 \%$ at the 12-week time point. Interestingly, only age, not diabetes, altered the levels of DOPAC (main duration effect: $F_{(1,17)}=$ 16.796, $p<0.001$; Fig. $1 B$ ). In terms of DA metabolism, the ratio of DA to DOPAC was not significantly altered due to diabetes, but did increase as the animals aged (main duration effect: $F_{(1,17)}=15.492$, $p=0.001$; Fig. 1C). Next, we assessed whether similar DA reduction occurred in DM mice. All mice injected with repeated low-dose STZ developed diabetes and maintained it throughout the experiment (Table 2). More importantly, similar to DM rats, DM mice had significantly lower DA levels, an $\sim 15 \%$ reduction, compared with CTRL mice (Student's $t$ value $=2.312, p=$ 0.039; Fig. $2 A$ ) at the 5 -week time point. No significant differences were found in DOPAC levels or DOPAC/DA ratios between the two groups (Fig. $2 B, C$ ). These results confirmed that diabetes leads to diminished retinal DA levels, as was reported previously (Nishimura and Kuriyama, 1985).

\section{Restoring DA content delayed diabetes- induced visual dysfunction}

To examine whether DA deficiency causes visual deficits in early DR, we investigated the effects of restoring DA levels with L-DOPA on visual function of DM mice. All STZ-treated DM mice were significantly hyperglycemic compared with CTRL mice (Table 2). Similar to our pre-

vious report in STZ-induced diabetic rats (Aung et al., 2013), DM $\mathrm{WT}+$ Veh mice exhibited significantly reduced spatial frequency thresholds (interaction effect: $F_{(12,82)}=4.644, p<0.001$; Fig. $3 A$ ) and contrast sensitivities (interaction effect: $F_{(12,82)}=6.425, p<$ 0.001; Fig. 3B), as early as 3-4 weeks after STZ. Moreover, the severity of visual deficits progressed over time. The deficit in spatial frequency threshold of DM WT + Veh group (compared with CTRL WT + Veh group) worsened from $7.0 \%$ at 3 weeks after STZ to $12.3 \%$ at 6 weeks after STZ, whereas the reduction in contrast sensitivity deteriorated from $12.8 \%$ at 3 weeks after STZ to $43.6 \%$ at 6 weeks after STZ. Conversely, the onset and progression of visual dysfunction was significantly delayed by chronic L-DOPA treatment (Fig. 3). The reduction in spatial frequency threshold of DM WT + L-DOPA group progressed from $2.4 \%$ at 3 weeks after STZ to $7.2 \%$ at 6 weeks after STZ, whereas the deficit in contrast sensitivity was only significant at 6 weeks after STZ, with an $18.0 \%$ reduction from CTRL animals. For comparison, L-DOPA treatment in CTRL mice did not cause
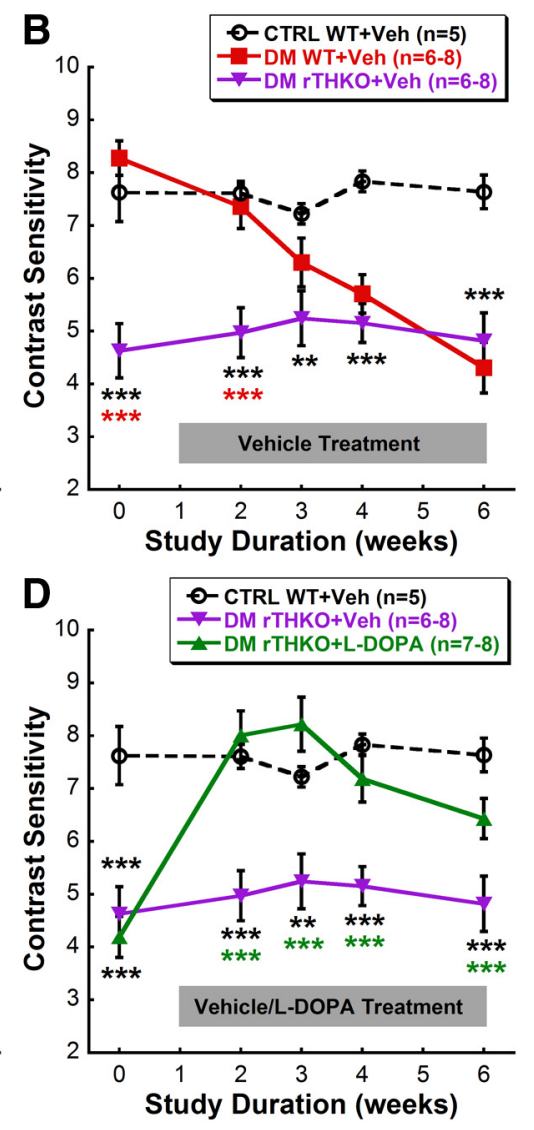

Figure 4. Genetic model of retinal DA deficiency (rTHKO) replicates early diabetes-induced visual dysfunction and could eh mice and the spatial frequency thresholds of the DM WT + Veh and DM rTHKO + Veh groups became indistinguishable at 3 weeks after STZ. $\boldsymbol{B}$, Similarly, the combination of rTHKO and diabetes did not further reduce contrast sensitivity guishable from 3 weeks after STZ onward. C, Chronic L-DOPA treatment restored the spatial frequency thresholds of $r$ THKO 作 mice significantly delayed the onset and slowed the progression of diabetes-induced impairment of spatial frein spatial frequency threshold DM rTHKO + L-DOPA mice exhibited significantly better contrast sensitivities than of the asterisk indicates the treatment group for which significance was reached. Note that the $y$-axis does not start early show the differences between treatment groups.

Table 3. Daily L-DOPA injections restore retinal dopamine levels

\begin{tabular}{llc}
\hline Treatment groups & $\begin{array}{l}\text { Sample } \\
\text { size }\end{array}$ & $\begin{array}{c}\text { Retinal dopamine } \\
\text { level (pg/retina) }\end{array}$ \\
\hline CTRL WT + Veh & 5 & $400 \pm 179^{*}$ \\
CTRL WT + L-DOPA & 5 & $399 \pm 179^{*}$ \\
DM rTHKO + Veh & 6 & $54 \pm 22$ \\
DM rTHKO + L-DOPA & 8 & $307 \pm 109$
\end{tabular}

As expected, rTHKO + Veh mice had significantly reduced DA levels from CTRL mice ( post hoc analysis, $p<0.05$ ) and daily injections of $\mathrm{L}-D O P A(10 \mathrm{mg} / \mathrm{kg})$ were able to increase retinal DA contents of DM rTHKO animals to levels comparable to those of CTRL animals.

*Significant difference between the respective treatment group and the DM rTHKO + Veh group.

significant changes in either spatial frequency threshold or contrast sensitivity. Furthermore, we did not observe any behavioral side effects such as dyskinesia with our current dosage of L-DOPA (10 mg/kg daily) in either CTRL or DM mice. We were cautious to select a dosage that was lower than the typical dosage used to induce dyskinesia (25 mg/kg; Cao et al., 2010; 


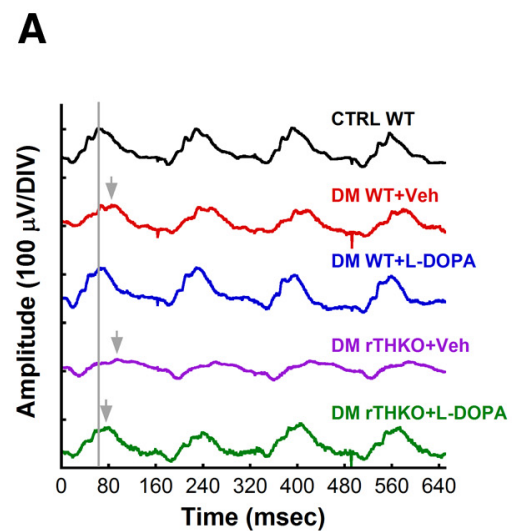

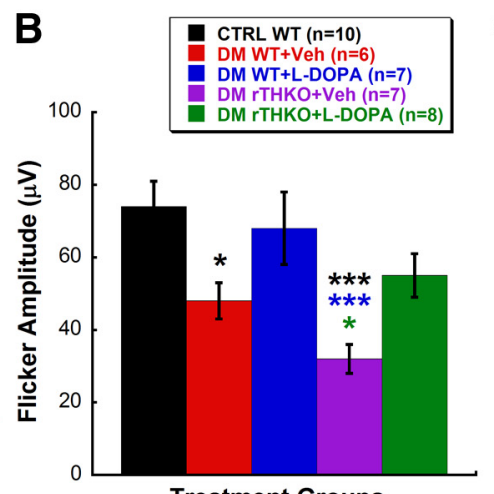

Treatment Groups

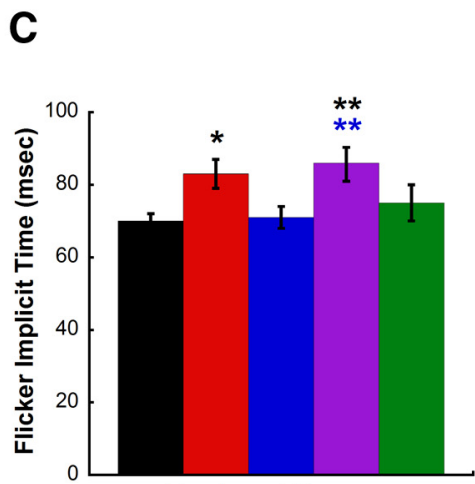

Treatment Groups

Figure 5. Changes in DA levels due to diabetes affect light-adapted retinal function. $A$, Representative raw waveforms to flicker stimuli (6 Hz) from CTRL WT (black), DM WT + Veh (red), DM WT + L-DOPA (blue), DM rTHKO + Veh (purple), and DM rTHKO + L-DOPA (green) at the 5-week time point. The gray line indicates the peak of the response in a CTRL WT mouse; gray arrows indicate the peak of the response when delayed. $\boldsymbol{B}, \boldsymbol{C}$, Average amplitudes $(\boldsymbol{B})$ and implicit times $(\boldsymbol{C})$ of the flicker responses from experimental groups at the 5 -week time point. DM WT + Veh mice had reduced (post hoc comparison, $p<0.05$ ) and delayed ( post hoc comparison, $p<0.05$ ) ERG responses compared with (TRL WT mice. L-DOPA treatment was able to restore ERG responses of DM WT mice to those of CTRL mice. Moreover, DM rTHKO + Veh mice with presumed lower DA content had severely reduced amplitudes than all other groups (post hoc comparison, $p<0.05$ ) except that of DM WT + Veh animals. DM rTHKO + Veh mice also exhibited delayed responses from (TRL WT and DM WT + L-DOPA animals ( post hoc comparison, $p<0.01$ ). The color of the asterisk indicates the treatment group in which significance was reached.
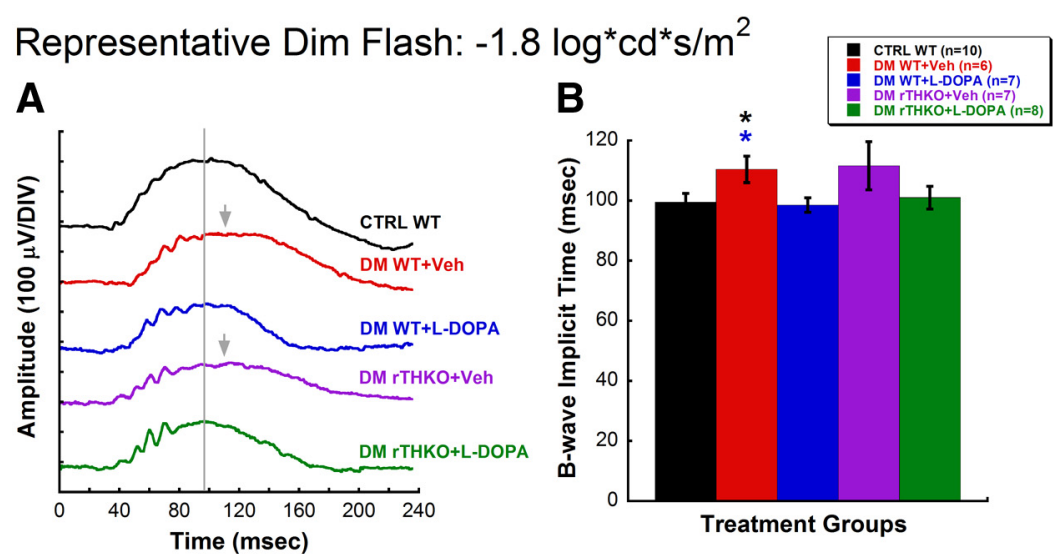

Representative Bright Flash: $0.6 \log ^{*} \mathrm{~cd}^{*} \mathrm{~s} / \mathrm{m}^{2}$
C

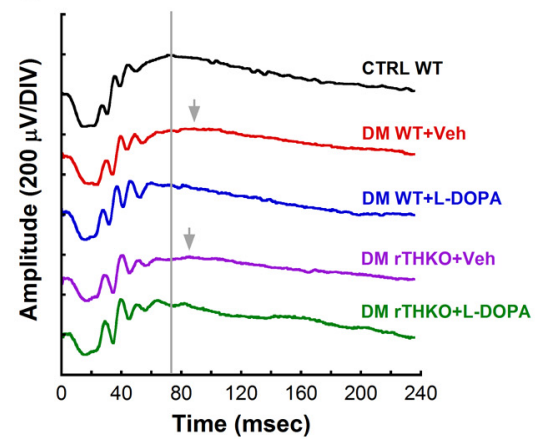

D

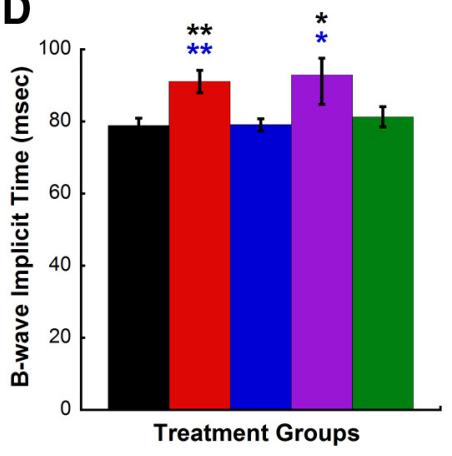

Figure 6. Changes in DA levels due to diabetes affect dark-adapted retinal function. $\boldsymbol{A}, \boldsymbol{B}$, Representative raw waveforms and average b-wave implicit times in response to a dim-flash stimulus $\left(-1.8 \log \mathrm{cd} \mathrm{s} / \mathrm{m}^{2}\right)$ at the 5 -week time point. $C, D$, Represen-

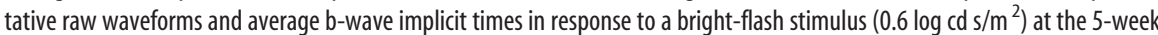
time point. The following colors represent each treatment group: black, CTRL WT; red, DM WT + Veh; blue, DM WT + L-DOPA; purple, DM rTHKO + Veh; and green, DM rTHKO + L-DOPA. The gray lines indicate the peak of the b-wave in a CTRL WT mouse; gray arrows indicate the peak of the response when delayed. DM WT + Veh mice exhibited significantly delayed b-wave responses elicited with both $\operatorname{dim}$ ( post hoc comparison, $p<0.05$ ) and bright (post hoc comparison, $p<0.01$ ) flash stimuli compared with CTRL WT and DM WT + L-DOPA mice. L-DOPA treatment was able to restore ERG responses of DM WT mice (DM WT + L-DOPA) to those of CTRL WT mice. Similarly, DM rTHKO + Veh mice had severely delayed responses from CTRL WT and DM WT + L-DOPA animals at the bright flash stimulus ( post hoc comparison, $p<0.05$ ). The color of the asterisk indicates the treatment group in which significance was reached.
Aguiar et al., 2013) yet could still increase retinal DA levels (Mao et al., 2010).

Retinal dysfunction underlies the dopamine-mediated visual deficits in diabetes

Because systemic injections of L-DOPA affect both brain and retinal dopaminergic systems, we tested the role of retinal DA deficiency underlying visual deficits in early-stage DR by assessing the effects of diabetes in mice with loss of retinal DA (rTHKO mice). We hypothesized that reduced retinal DA content is a major contributing factor to the early visual deficits, so diabetes in rTHKO mice should not result in a further decline in their visual function. First, we found that rTHKO mice had reduced spatial frequency thresholds (10.4\% lower than CTRL; Fig. $4 A, C)$ and contrast sensitivities (39.3\% lower than CTRL; Fig. $4 B, D$ ) at baseline (before diabetes induction), which were similar in severity, as described previously (Jackson et al., 2012). More importantly, visual function of the DM rTHKO + Veh group did not further deteriorate after induction of diabetes and maintained the same level of deficit compared with the CTRL group throughout the study period (Fig. $4 A, B$ ). Although DM rTHKO + Veh mice began the study with significantly lower spatial frequency thresholds (interaction effect: $F_{(12,95)}=8.861, p<0.001$; Fig. $4 A$ ) and contrast sensitivities (interaction effect: $F_{(12,95)}=13.348, p<0.001$; Fig. $4 B$ ) than those of DM WT + Veh mice, the visual function levels of both groups began to coincide starting at 3 weeks after STZ. To show that DA defi- 
ciency could account for the visual dysfunctions observed in DM rTHKO mice, we treated a separate cohort of DM rTHKO mice with L-DOPA. As shown in Figure 4, $C$ and D, L-DOPA treatment significantly improved visual functions of DM rTHKO + L-DOPA mice that lasted for the duration of the study (post hoc comparison, $p<0.001)$.

To validate that daily intraperitoneal injections of L-DOPA were able to increase retinal DA levels, we measured retinal dopamine contents of the following four groups of animals: CTRL WT + Veh, CTRL WT + L-DOPA, DM rTHKO + Veh, and DM rTHKO + L-DOPA. As expected, the retinal TH deficiency in the rTHKO mice greatly diminished DA levels compared with both CTRL groups (one-way ANOVA with ranks, $\mathrm{H}=12.092$ with 3 degrees of freedom, $p=0.007$; Table 3). Conversely, L-DOPA treatment was able to restore the retina DA contents of rTHKO mice to levels comparable to those of CTRL animals. L-DOPA did not significantly increase the DA levels of CTRL mice. Overall, these results provide evidence that retinal DA reduction contributes to the visual defects in early-stage DR and that restoration of retinal DA content with L-DOPA treatment can slow the onset and progression of visual loss.

To confirm our previous hypothesis that retinal dysfunction in early-stage DR contributes to visual deficits (Aung et al., 2013) and to further support a role for retinal DA deficiency in the visual deficits, we investigated whether L-DOPA treatment improved retinal function as well (assessed by ERG). Because OKT responses were recorded under photopic conditions, we first examined isolated cone pathway function by exposing lightadapted animals to flicker stimuli. The CTRL group shown here and in subsequent RT-PCR analyses includes both CTRL WT + Veh and CTRL WT + L-DOPA animals because no significant differences were detected between them. We found that flicker responses in DM WT + Veh mice were significantly reduced (interaction effect: $F_{(4,33)}=6.032, p<0.01$; Fig. $5 B$ ) and delayed (interaction effect: $F_{(4,33)}=3.621, p<0.05$; Fig. $5 C$ ) compared with the CTRL animals. More importantly, L-DOPA treatment ameliorated these deficits, restoring the flicker responses of DM WT + L-DOPA mice to levels similar to those of CTRL animals (Fig. 5). In mice with retinal DA deficiency (DM rTHKO + Veh), we observed an even greater reduction ( post hoc comparison, $p<$ 0.001 ) and delay (post hoc comparison, $p<0.01$ ) in flicker responses compared with CTRL mice (Fig. 5). Once again, administering L-DOPA was able to partially restore cone pathway functions of DM rTHKO mice to CTRL levels (Fig. 5).

To determine whether L-DOPA treatment was also beneficial for rod pathway function, we conducted dark-adapted ERGs on the same groups of animals. First, no consistent differences were observed in the a-waves, indicating no alterations in the photoreceptoral response at such early stages of diabetes (data not shown). Next, we examined the postreceptoral function (i.e., b-wave) of these animals. We found that DM WT + Veh animals exhibited significantly delayed $b$-waves from both CTRL and DM $\mathrm{WT}+\mathrm{L}$-DOPA groups under both $\operatorname{dim}$ (rods-dominated response: $F_{(2,20)}=3.688, p=0.042$; Fig. $6 A, B$ ) and bright (mixed rods and cones response: $F_{(2,20)}=8.311, p=0.002$; Fig. $6 C, D$ ) flashes. Importantly, L-DOPA treatment reversed the ERG deficits, because no significant difference was detected in the implicit times of the b-waves between CTRL and DM WT + L-DOPA groups. When we repeated the experiment with $\mathrm{rTHKO}$ animals, we found that the implicit times of the b-wave responses of DM rTHKO + Veh group under both $\operatorname{dim}(111.6 \pm 8.0 \mathrm{~ms})$ and bright $(92.9 \pm 8.1 \mathrm{~ms})$ flashes were indistinguishable from those of DM WT + Veh group (dim: $110.4 \pm 4.4$ ms and bright: $91.1 \pm$

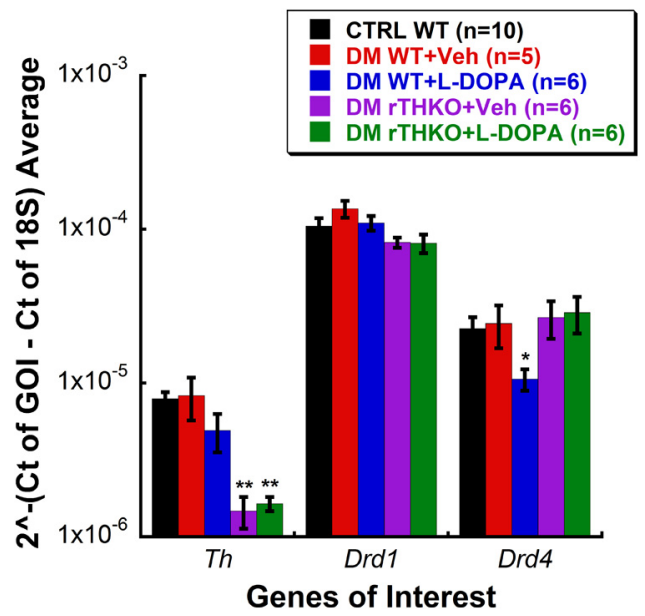

Figure 7. mRNA levels of the examined dopaminergic system-related genes. rTHKO mice had significantly lower expressions of $T h$ than CTRL WT mice ( $t$ test, $p<0.01$ ). Diabetes in DM WT mice did not induce a significant change in $m$ RNA levels of $T h, D r d 1$, or Drd4 compared with the CTRL WT mice. Interestingly, L-DOPA treatment caused a downregulation of Drd4 ( $t$ test, $p<0.05$ ), but not of Drd1, in DM WT mice compared with CTRL WT mice. Note that the $y$-axis refers to averaged $2^{-\Delta \mathrm{Ct}}$ values, with $\Delta \mathrm{Ct}$ calculated by subtracting cycle threshold $(\mathrm{Ct})$ of $18 \mathrm{~S}$ from $\mathrm{Ct}$ of gene of interest ( $\mathrm{GOI}$ ). The asterisk indicates significant difference between the respective treatment group and the CTRL WT group.

Table 4. Fold changes in mRNA levels of genes of interest for each experimental group compared to CTRL WT group

\begin{tabular}{lcccc}
\hline Treatment group & $\begin{array}{l}\text { Sample } \\
\text { size }\end{array}$ & $\begin{array}{l}\text { Th } \\
\text { expression }\end{array}$ & $\begin{array}{l}\text { Drd1 } \\
\text { expression }\end{array}$ & $\begin{array}{l}\text { Drd4 } \\
\text { expression }\end{array}$ \\
\hline CTRL WT & 10 & 1 & 1 & 1 \\
DM WT + Veh & 5 & 1.05 & 1.30 & 1.08 \\
DM WT + L-DOPA & 6 & -1.61 & 1.05 & $-2.14^{*}$ \\
DM rTHKO + Veh & 6 & $-5.38^{* *}$ & -1.28 & 1.18 \\
DM rTHKO + L-DOPA & 6 & $-4.80^{* *}$ & -1.29 & 1.27 \\
\hline
\end{tabular}

Significances depicted here reflect those indicated in Figure 7.

*Significant difference between the respective treatment group and the CTRL WT group.

$3.1 \mathrm{~ms}$; Fig. 6). Administration of L-DOPA to rTHKO mice showed a strong, although not statistically significant, trend for improvement in b-wave implicit times under both dim and bright stimuli (Fig. 6). In terms of b-wave amplitude, we found that both groups of DM rTHKO mice ( \pm L-DOPA) showed significantly reduced responses from the CTRL WT animals at both $\operatorname{dim}\left(F_{(4,34)}=4.497, p=0.005\right)$ and bright $\left(F_{(4,34)}=3.197, p=\right.$ 0.025 ) flash stimuli (data not shown). Nonetheless, these additional analyses replicated our previous findings of early inner retinal dysfunctions in both rod and cone pathways due to diabetes (Aung et al., 2013). Collectively, the ERG data also reinforce our hypotheses that retinal dysfunction may partially underlie early diabetes-associated visual defects and that L-DOPA therapy was able to improve retinal function and thereby slow the progression of visual loss.

\section{Retinal transcript levels of key dopamine proteins unchanged with diabetes}

Because our results showed that diabetes produced retinal DA deficiency, we were interested in determining whether changes in Th transcript levels may mediate this pathology. Using real-time RT-PCR, we found that diabetes did not significantly alter Th levels (Fig. 7, Table 4), although L-DOPA treatment resulted in a trend for Th downregulation. The specificity of our Th primers was confirmed, because we found a $>4$-fold reduction in $T h$ 
A

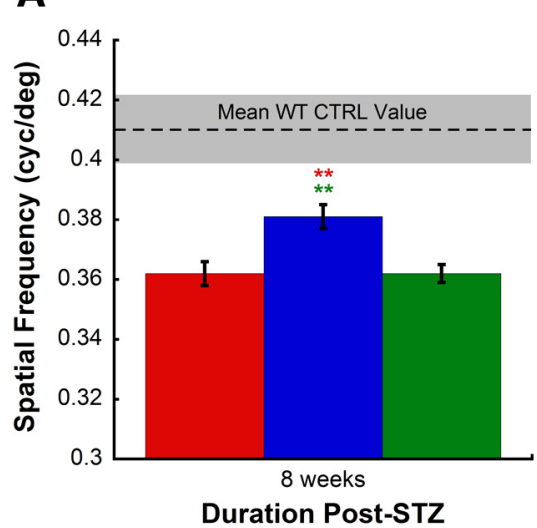

B

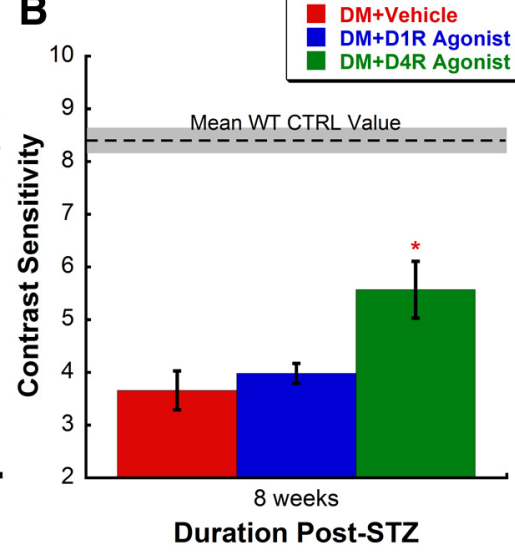

Figure 8. Distinct improvement in OKT responses of 8-week DM WT mice $(n=7)$ after treatments with selective dopamine receptor agonists. $\boldsymbol{A}$, Spatial frequency thresholds of DM WT mice improved significantly when treated with D1 receptor agonist (post hoc analysis, $p<0.01$ ). Treatment with the D4 receptor agonist failed to improve spatial frequency thresholds. $\boldsymbol{B}$, Conversely, DM WT mice showed significantly enhanced contrast sensitivity levels only when treated with D4 agonist (post hoc analysis, $p<0.05$ ). However, neither treatment restored visual functions (spatial frequency threshold and contrast sensitivity) of DM WT mice to CTRL WT levels, indicated by the dashed lines with their variance ( \pm SEM) represented by gray boxes. Note that the $y$-axis does not start at zero; it is modified to more clearly show the differences between treatment groups.

expression in rTHKO mice (Student's $t$ values: DM rTHKO + $\mathrm{Veh}=5.964$ and DM rTHKO $+\mathrm{L}-\mathrm{DOPA}=5.928, p<0.01$; Fig. 7 , Table 4) regardless of L-DOPA treatment. Next, we were interested in determining whether diabetes affected transcript levels of DA receptors, specifically D1 receptor (Drd1) and D4 receptor (Drd4), which are selectively involved in spatial frequency threshold and contrast sensitivity, respectively (Jackson et al., 2012). We found no significant changes in the transcript levels of Drd1 and Drd4 (Fig. 7, Table 4). Interestingly, we found that L-DOPA treatment led to a significant downregulation of Drd4 transcript levels in DM WT mice (Student's $t$ value: DM WT + L-DOPA $=2.154, p<0.05$; Fig. 7 , Table 4 ), which was consistent with previous results suggesting DA-dependent regulation of Drd4 expression level (Jackson et al., 2011).

\section{Selective improvement in visual function with dopamine receptor agonists}

Next, we investigated whether activation of DA pathways with selective receptor agonists could reverse visual defects in animals with established diabetes by inducing diabetes in a group of WT mice with STZ and maintaining them for 8 weeks. After 8 weeks of diabetes, we injected the animals with vehicle, D1 receptor (D1R) agonist (SKF38393), and D4 receptor (D4R) agonist (PD168077). We found that DA agonist treatment was able to restore both spatial frequency threshold $\left(F_{(2,10)}=8.550, p=\right.$ 0.007; Fig. $8 A)$ and contrast sensitivity $\left(F_{(2,10)}=5.321, p=0.027\right.$; Fig. $8 B$ ), but not to the CTRL WT levels. More interestingly, we found that administration of D1R agonist only improved spatial frequency threshold, whereas administration of D4R agonist only improved contrast sensitivity. These findings replicate those of Jackson et al. (2012) in normoglycemic animals and suggest that diabetes does not alter the distinct roles of D1R and D4R on visual function. More importantly, these results indicate that treatments targeting the dopaminergic system could be beneficial to patients with established diabetes.

\section{Discussion}

We conducted noninvasive functional assessments in diabetic rodents and postmortem analyses of the dopaminergic pathways in retinal tissues to examine the overall role of retinal DA in early visual deficits due to diabetes. We found that diabetes produced retinal DA deficiency and that pharmacologic replacement of DA or stimulation of DA receptors ameliorated diabetes-associated visual dysfunction.

\section{Dopamine deficiency in diabetes}

In accordance with previous studies (Trulson and Himmel, 1983; Nishimura and Kuriyama, 1985), our data show reduced retinal DA contents in both DM rats and mice as early as $4-5$ weeks after STZ (Figs. 1, 2). Dysregulation at multiple sites of DA metabolic processing has been postulated to reduce DA abundance, but published results show inconsistencies. First, it is possible that retinal DA reduction in diabetes originates from decreased biosynthesis. Several studies have documented diminished L-DOPA accumulations in diabetic retinas with normal activity levels of $\mathrm{TH}$, thereby concluding that DA deficiency is due to reduced tyrosine level in the retina (Fernstrom et al., 1984, 1986). However, others indicate that DA alteration is due to decreased TH activity, leading to reduced rate of tyrosine hydroxylation (Northington et al., 1985). Although the Th transcript levels did not change due to diabetes in the present study (Fig. 7, Table 4), some studies have suggested that retinal TH protein levels are downregulated (Seki et al., 2004), presumably from increased posttranslational processing of the $\mathrm{TH}$ proteins or apoptotic loss of dopaminergic neurons (Gastinger et al., 2006). These inconsistencies may be attributed to animal strain differences, variable glycemic controls, or different durations of hyperglycemia across studies (Kirwin et al., 2009; Kern et al., 2010a; Robinson et al., 2012). A second plausible mechanism for reduced DA levels in diabetic animals is enhanced turnover of DA. Although we did not measure DA turnover rate directly in this study, we found that metabolism of DA to DOPAC (DOPAC/DA ratio), an indirect assessment of DA turnover (Witkovsky, 2004), was not altered by diabetes (Figs. 1, 2). Mitochondrial dysfunction (Kowluru, 2005) and oxidative stress associated with diabetes (Kowluru and Chan, 2007; Sasaki et al., 2010) may also result in enhanced oxidation of DA and render it inactive biologically-a possibility that should be explored in future studies.

Aside from dysfunction of the dopaminergic neurons, disturbances in light transmission and/or retinal circadian clock pathways may alter retinal DA content because retinal DA synthesis and release are tightly regulated by such mechanisms (Iuvone et al., 1978; Doyle et al., 2002). Because cataract is a common complication of diabetes (Obrosova et al., 2010), increased opacity of the lens could attenuate light transmission to the retina and thereby impair light-induced upregulation of DA in diabetic retinas. However, we found reduced retinal DA levels starting at 4 weeks after STZ (Fig. 1A), before significant development of cataract, at 6 weeks in STZ-induced diabetic rats (Aung et al., 2013). Moreover, despite the lack of cataract development in our STZ mice at the 5-week time point, we still found reduced retinal DA levels in these mice (Fig. 2). Therefore, diminished light input is not a likely contributing factor for early diabetes-induced retinal DA deficiency. In regard to altered circadian clocks underling DA deficiency in diabetes, studies have shown that both retinal and 
peripheral circadian clocks are dysfunctional in diabetic animals (Young et al., 2002; Herichová et al., 2005; Busik et al., 2009; do Carmo Buonfiglio et al., 2011) and mice with circadian clock mutations recapitulate diabetic phenotypes (Marcheva et al., 2010; Doi, 2012; Bhatwadekar et al., 2013). Therefore, further research is warranted to explore how abnormal circadian pathways in a diabetic retina can lead to alterations in the dopaminergic system and to elucidate other potential upstream mediators (e.g., oxidative stress, inflammation, vascular dysfunction) that can lead to DA deficiency.

\section{Dopamine deficiency and visual deficits}

Our data suggest that disruptions in the retinal dopaminergic system due to diabetes produce profound visual deficits. Not only does the onset of DA reductions coincide with the onset of visual defects, the results from $\mathrm{L}-\mathrm{DOPA}$ and DA receptor agonist treatments provide evidence for the causal role of DA deficiency in visual loss in early-stage DR. These results are consistent with studies on multiple disorders with known abnormalities in dopamine signaling, such as Parkinson's disease and retinitis pigmentosa, that have been shown to develop visual deficits (Brandies and Yehuda, 2008; Bodis-Wollner, 2009). However, visual symptoms in disorders that involve the brain may not be completely due to local effects of retinal DA deficiency because DA is involved in multiple levels of mammalian visual processing, including the thalamic and cortical relays. In addition, examining visual defects in retinitis pigmentosa models due to depressed retinal dopaminergic system is complicated by the severe vision loss associated with photoreceptor degeneration (Nir and Iuvone, 1994; Brandies and Yehuda, 2008; Atkinson et al., 2013). Therefore, our findings, especially with the retinal-specific ERG results and the use of rTHKO mice, corroborate the role of diminished retinal DA bioavailability in visual dysfunction. The effect is unlikely due to degeneration of retinal neurons because the examined time points were before reports of retinal degeneration in diabetes (Martin et al., 2004; Kern et al., 2010b; Villarroel et al., 2010; Barber et al., 2011). Furthermore, no evidence of retinal degeneration was observed due to deletion of Th in the original characterization of the rTHKO mice (Jackson et al., 2012). However, the loss of retinal DA in these mice was incomplete. The retinal DA levels and the numbers of TH-positive cells in the rTHKO mice were $\sim 10 \%$ of wild-type controls (Jackson et al., 2012), similar to the DA levels observed in the present study (Table 3). Therefore, there may be a small number of dopaminergic amacrine cells in which the gene was not disrupted, resulting in a low level of Th expression (Fig. 7). It is unknown whether complete elimination of retinal DA would have a more severe effect on cell survival, retinal function, and ultimately visual function. Nonetheless, examination of the potential neuroprotective effects of chronic activation of DA pathways in a diabetic retina would be interesting because some studies have found that stimulation of DA pathways, especially through D1R activation, could protect retinal neurons from injury due to oxidative stress or glutamate neurotoxicity under in vitro conditions (Kashii et al., 1994; Yamauchi et al., 2003; Li et al., 2012).

How, then, does DA deficiency lead to visual deficits? Jackson et al. (2012) reported that the global effects of DA on vision are mediated through actions of D1 and D4 receptors, possibly by uncoupling gap junctions in distinct retinal neurons. D1Rs are expressed on horizontal cells, where their activation uncouples electrical synapses and restricts current flow between these cells. Horizontal cell uncoupling may narrow the ganglion cell centersurround receptive field and thereby produce sharper visual acu- ity (Witkovsky, 2004; Bloomfield and Völgyi, 2009). Therefore, a diabetes-mediated attenuation of DA signaling through D1Rs could expand the receptive fields of ganglion cells and lead to lower spatial frequency thresholds (Jackson et al., 2012). Conversely, D4Rs are localized to photoreceptors, where the binding of DA to the receptor limits the transmission of signals between rods and cones via electrical synapses (Witkovsky, 2004; Bloomfield and Völgyi, 2009). Therefore, a decrease in D4R activation could enhance coupling of rods and cones and result in shunting of cone signals into rod pathways. Under rod-saturating, lightadapted conditions, this could diminish contrast sensitivity (Jackson et al., 2012). However, it is important to recognize the possibility of diabetes altering melatonin (Hikichi et al., 2011; do Carmo Buonfiglio et al., 2011), a neuromodulator with a reciprocal and antagonistic relationship to DA, which may potentiate the effects of DA reduction on visual deficits (Tosini et al., 2012). Although the mice used in the study were on the C57BL/6 background with minimal melatonin synthesis, future testing should be conducted to understand the contributions of dopaminemelatonin interactions to visual dysfunction in diabetes. Furthermore, although $\operatorname{Drd1}$ and $\operatorname{Drd} 4$ transcript levels were not affected by diabetes in our model (Fig. 7, Table 4), it is still possible that dysregulation in the protein or activity levels of DA receptors could augment the effects of DA deficiency on vision.

\section{Diabetes-induced dopamine deficiency and clinical relevance} In conclusion, we found that reduced retinal DA content is an underlying factor for the early visual deficits observed in DR. These data support our previous hypothesis that dysfunction in the neural retina due to diabetes is a contributing factor to visual dysfunction because L-DOPA treatment significantly improved retinal function and thereby vision. Importantly, our results have translational relevance because we discovered that restoring DA levels (L-DOPA) or activating DA pathways (DA receptor agonists) in the retina may serve as therapeutic interventions for early-stage DR. Last, exploring how DA deficiency may underlie other diabetes-associated neuropathies and understanding why dopaminergic neurons are one of the retinal cell types susceptible to these diabetic insults may reveal new therapeutic avenues for DR and other disorders that involve dopamine deficiency.

\section{References}

Abu El-Asrar AM, Dralands L, Missotten L, Geboes K (2007) Expression of antiapoptotic and proapoptotic molecules in diabetic retinas. Eye (Lond) 21:238-245. CrossRef Medline

Abu-El-Asrar AM, Dralands L, Missotten L, Al-Jadaan IA, Geboes K (2004) Expression of apoptosis markers in the retinas of human subjects with diabetes. Invest Ophthalmol Vis Sci 45:2760-2766. CrossRef Medline

Aguiar AS Jr, Moreira EL, Hoeller AA, Oliveira PA, Córdova FM, Glaser V, Walz R, Cunha RA, Leal RB, Latini A, Prediger RD (2013) Exercise attenuates levodopa-induced dyskinesia in 6-hydroxydopamine-lesioned mice. Neuroscience 243:46-53. CrossRef Medline

Akimov NP, Rentería RC (2012) Spatial frequency threshold and contrast sensitivity of an optomotor behavior are impaired in the Ins2Akita mouse model of diabetes. Behav Brain Res 226:601-605. CrossRef Medline

Antonetti DA, Barber AJ, Bronson SK, Freeman WM, Gardner TW, Jefferson LS, Kester M, Kimball SR, Krady JK, LaNoue KF, Norbury CC, Quinn PG, Sandirasegarane L, Simpson IA, Simpson IA (2006) Diabetic retinopathy: seeing beyond glucose-induced microvascular disease. Diabetes 55 : 2401-2411. CrossRef Medline

Atkinson CL, Feng J, Zhang DQ (2013) Functional integrity and modification of retinal dopaminergic neurons in the rd1 mutant mouse: roles of melanopsin and GABA. J Neurophysiol 109:1589-1599. CrossRef Medline

Aung MH, Kim MK, Olson DE, Thule PM, Pardue MT (2013) Early visual deficits in streptozotocin-induced diabetic Long-Evans rats. Invest Ophthalmol Vis Sci 54:1370-1377. CrossRef Medline 
Barber AJ (2003) A new view of diabetic retinopathy: a neurodegenerative disease of the eye. Prog Neuropsychopharmacol Biol Psychiatry 27:283290. CrossRef Medline

Barber AJ, Gardner TW, Abcouwer SF (2011) The significance of vascular and neural apoptosis to the pathology of diabetic retinopathy. Invest Ophthalmol Vis Sci 52:1156-1163. CrossRef Medline

Bhatwadekar AD, Yan Y, Qi X, Thinschmidt JS, Neu MB, Li Calzi S, Shaw LC, Dominiguez JM, Busik JV, Lee C, Boulton ME, Grant MB (2013) Per2 mutation recapitulates the vascular phenotype of diabetes in the retina and bone marrow. Diabetes 62:273-282. CrossRef Medline

Björklund A, Dunnett SB (2007) Dopamine neuron systems in the brain: an update. Trends Neurosci 30:194-202. CrossRef Medline

Bloomfield SA, Völgyi B (2009) The diverse functional roles and regulation of neuronal gap junctions in the retina. Nat Rev Neurosci 10:495-506. CrossRef Medline

Bodis-Wollner I (2009) Retinopathy in Parkinson Disease. J Neural Transm 116:1493-1501. CrossRef Medline

Brandies R, Yehuda S (2008) The possible role of retinal dopaminergic system in visual performance. Neurosci Biobehav Rev 32:611-656. CrossRef Medline

Busik JV, Tikhonenko M, Bhatwadekar A, Opreanu M, Yakubova N, Caballero S, Player D, Nakagawa T, Afzal A, Kielczewski J, Sochacki A, Hasty S, Li Calzi S, Kim S, Duclas SK, Segal MS, Guberski DL, Esselman WJ, Boulton ME, Grant MB (2009) Diabetic retinopathy is associated with bone marrow neuropathy and a depressed peripheral clock. J Exp Med 206:2897-2906. CrossRef Medline

Cai J, Boulton M (2002) The pathogenesis of diabetic retinopathy: old concepts and new questions. Eye (Lond) 16:242-260. CrossRef Medline

Cao X, Yasuda T, Uthayathas S, Watts RL, Mouradian MM, Mochizuki H, Papa SM (2010) Striatal overexpression of DeltaFosB reproduces chronic levodopa-induced involuntary movements. J Neurosci 30:73357343. CrossRef Medline

Clee SM, Attie AD (2007) The genetic landscape of type 2 diabetes in mice. Endocr Rev 28:48-83. CrossRef Medline

Congdon NG, Friedman DS, Lietman T (2003) Important causes of visual impairment in the world today. JAMA 290:2057-2060. CrossRef Medline

do Carmo Buonfiglio D, Peliciari-Garcia RA, do Amaral FG, Peres R, Nogueira TC, Afeche SC, Cipolla-Neto J (2011) Early-stage retinal melatonin synthesis impairment in streptozotocin-induced diabetic wistar rats. Invest Ophthalmol Vis Sci 52:7416-7422. CrossRef Medline

Doi M (2012) Circadian clock-deficient mice as a tool for exploring disease etiology. Biol Pharm Bull 35:1385-1391. CrossRef Medline

Douglas RM, Alam NM, Silver BD, McGill TJ, Tschetter WW, Prusky GT (2005) Independent visual threshold measurements in the two eyes of freely moving rats and mice using a virtual-reality optokinetic system. Vis Neurosci 22:677-684. CrossRef Medline

Doyle SE, McIvor WE, Menaker M (2002) Circadian rhythmicity in dopamine content of mammalian retina: role of the photoreceptors. J Neurochem 83:211-219. CrossRef Medline

Fernstrom JD, Fernstrom MH (2007) Tyrosine, phenylalanine, and catecholamine synthesis and function in the brain. J Nutr 137:1539S-1547S; discussion 1548S. Medline

Fernstrom MH, Volk EA, Fernstrom JD (1984) In vivo tyrosine hydroxylation in the diabetic rat retina: effect of tyrosine administration. Brain Res 298:167-170. CrossRef Medline

Fernstrom MH, Volk EA, Fernstrom JD, Iuvone PM (1986) Effect of tyrosine administration on dopa accumulation in light- and dark-adapted retinas from normal and diabetic rats. Life Sci 39:2049-2057. CrossRef Medline

Fletcher EL, Phipps JA, Ward MM, Puthussery T, Wilkinson-Berka JL (2007) Neuronal and glial cell abnormality as predictors of progression of diabetic retinopathy. Curr Pharm Des 13:2699-2712. CrossRef Medline

Frank RN (2004) Diabetic retinopathy. N Engl J Med 350:48-58. CrossRef Medline

Gastinger MJ, Singh RS, Barber AJ (2006) Loss of cholinergic and dopaminergic amacrine cells in streptozotocin-diabetic rat and Ins2Akitadiabetic mouse retinas. Invest Ophthalmol Vis Sci 47:3143-3150. CrossRef Medline

Ghirlanda G, Di Leo MA, Caputo S, Cercone S, Greco AV (1997) From functional to microvascular abnormalities in early diabetic retinopathy. Diabetes Metab Rev 13:15-35. CrossRef Medline

Herichová I, Zeman M, Stebelová K, Ravingerová T (2005) Effect of streptozotocin-induced diabetes on daily expression of per2 and dbp in the heart and liver and melatonin rhythm in the pineal gland of Wistar rat. Mol Cell Biochem 270:223-229. CrossRef Medline

Herrmann R, Heflin SJ, Hammond T, Lee B, Wang J, Gainetdinov RR, Caron MGG, Eggers ED, Frishman LJ, McCall MA a, Arshavsky VY (2011) Rod vision is controlled by dopamine-dependent sensitization of rod bipolar cells by GABA. Neuron 72:101-110. CrossRef Medline

Hikichi T, Tateda N, Miura T (2011) Alteration of melatonin secretion in patients with type 2 diabetes and proliferative diabetic retinopathy. Clin Ophthalmol 5:655-660. CrossRef Medline

Iuvone PM, Galli CL, Garrison-Gund CK, Neff NH (1978) Light stimulates tyrosine hydroxylase activity and dopamine synthesis in retinal amacrine neurons. Science 202:901-902. CrossRef Medline

Jackson CR, Chaurasia SS, Hwang CK, Iuvone PM (2011) Dopamine $\mathrm{D}_{4}$ receptor activation controls circadian timing of the adenylyl cyclase 1/cyclic AMP signaling system in mouse retina. Eur J Neurosci 34:57-64. CrossRef Medline

Jackson CR, Ruan GX, Aseem F, Abey J, Gamble K, Stanwood G, Palmiter RD, Iuvone PM, McMahon DG (2012) Retinal dopamine mediates multiple dimensions of light-adapted vision. J Neurosci 32:9359-9368. CrossRef Medline

Jackson DM, Ross SB, Hashizume M (1988) Further studies on the interaction between bromocriptine and SKF38393 in reserpine and alpha methyl-para-tyrosine-treated mice. Psychopharmacology (Berl) 94:321327. Medline

Jackson GR, Barber AJ (2010) Visual dysfunction associated with diabetic retinopathy. Curr Diab Rep 10:380-384. CrossRef Medline

Kashii S, Takahashi M, Mandai M, Shimizu H, Honda Y, Sasa M, Ujihara H, Tamura Y, Yokota T, Akaike A (1994) Protective action of dopamine against glutamate neurotoxicity in the retina. Invest Ophthalmol Vis Sci 35:685-695. Medline

Kern TS, Barber AJ (2008) Retinal ganglion cells in diabetes. J Physiol 586: 4401-4408. CrossRef Medline

Kern TS, Miller CM, Tang J, Du Y, Ball SL, Berti-Matera L (2010a) Comparison of three strains of diabetic rats with respect to the rate at which retinopathy and tactile allodynia develop. Mol Vis 16:1629-1639. Medline

Kern TS, Tang J, Berkowitz BA (2010b) Validation of structural and functional lesions of diabetic retinopathy in mice. Mol Vis 16:2121-2131. Medline

King H, Aubert RE, Herman WH (1998) Global burden of diabetes, 19952025: prevalence, numerical estimates, and projections. Diabetes Care 21:1414-1431. CrossRef Medline

Kirwin SJ, Kanaly ST, Linke NA, Edelman JL (2009) Strain-dependent increases in retinal inflammatory proteins and photoreceptor FGF-2 expression in streptozotocin-induced diabetic rats. Invest Ophthalmol Vis Sci 50:5396-5404. CrossRef Medline

Kirwin SJ, Kanaly ST, Hansen CR, Cairns BJ, Ren M, Edelman JL (2011) Retinal gene expression and visually evoked behavior in diabetic LongEvans rats. Invest Ophthalmol Vis Sci 52:7654-7663. CrossRef Medline

Klein BE (2007) Overview of epidemiologic studies of diabetic retinopathy. Ophthalmic Epidemiol 14:179-183. CrossRef Medline

Kowluru RA (2005) Diabetic retinopathy: mitochondrial dysfunction and retinal capillary cell death. Antioxid Redox Signal 7:1581-1587. CrossRef Medline

Kowluru RA, Chan PS (2007) Oxidative stress and diabetic retinopathy. Exp Diabetes Res 2007:43603. Medline

Li G-Y, Li T, Fan B, Zheng YC, Ma TH (2012) The $\mathrm{D}_{1}$ dopamine receptor agonist, SKF83959, attenuates hydrogen peroxide-induced injury in RGC-5 cells involving the extracellular signal-regulated kinase/p38 pathways. Mol Vis 18:2882-2895. Medline

Livak KJ, Schmittgen TD (2001) Analysis of relative gene expression data using real-time quantitative PCR and the 2(-Delta Delta C(T)) Method. Methods 25:402-408. CrossRef Medline

Mao J, Liu S, Qin W, Li F, Wu X, Tan Q (2010) Levodopa inhibits the development of form-deprivation myopia in guinea pigs. Optom Vis Sci 87:53-60. CrossRef Medline

Marcheva B, Ramsey KM, Buhr ED, Kobayashi Y, Su H, Ko CH, Ivanova G, Omura C, Mo S, Vitaterna MH, Lopez JP, Philipson LH, Bradfield CA, Crosby SD, JeBailey L, Wang X, Takahashi JS, Bass J (2010) Disruption of the clock components CLOCK and BMAL1 leads to hypoinsulinaemia and diabetes. Nature 466:627-631. CrossRef Medline 
Martin PM, Roon P, Van Ells TK, Ganapathy V, Smith SB (2004) Death of retinal neurons in streptozotocin-induced diabetic mice. Invest Ophthalmol Vis Sci 45:3330-3336. CrossRef Medline

Moreland RB, Patel M, Hsieh GC, Wetter JM, Marsh K, Brioni JD (2005) A-412997 is a selective dopamine D4 receptor agonist in rats. Pharmacol Biochem Behav 82:140-147. CrossRef Medline

Muir ER, Rentería RC, Duong TQ (2012) Reduced ocular blood flow as an early indicator of diabetic retinopathy in a mouse model of diabetes. Invest Ophthalmol Vis Sci 53:6488-6494. CrossRef Medline

Nir I, Iuvone PM (1994) Alterations in light-evoked dopamine metabolism in dystrophic retinas of mutant rds mice. Brain Res 649:85-94. CrossRef Medline

Nir I, Haque R, Iuvone PM (2000) Diurnal metabolism of dopamine in the mouse retina. Brain Res 870:118-125. CrossRef Medline

Nishimura C, Kuriyama K (1985) Alterations in the retinal dopaminergic neuronal system in rats with streptozotocin-induced diabetes. J Neurochem 45:448-455. CrossRef Medline

Northington FK, Hamill RW, Banerjee SP (1985) Dopamine-stimulated adenylate cyclase and tyrosine hydroxylase in diabetic rat retina. Brain Res 337:151-154. CrossRef Medline

Obrosova IG, Chung SS, Kador PF (2010) Diabetic cataracts: mechanisms and management. Diabetes Metab Res Rev 26:172-180. CrossRef Medline

Pozdeyev N, Tosini G, Li L, Ali F, Rozov S, Lee RH, Iuvone PM (2008) Dopamine modulates diurnal and circadian rhythms of protein phosphorylation in photoreceptor cells of mouse retina. Eur J Neurosci 27: 2691-2700. CrossRef Medline

Prusky GT, Alam NM, Douglas RM (2006) Enhancement of vision by monocular deprivation in adult mice. J Neurosci 26:11554-11561. CrossRef Medline

Puk O, Dalke C, Hrabé de Angelis M, Graw J (2008) Variation of the response to the optokinetic drum among various strains of mice. Front Biosci 13:6269-6275. Medline

Robinson R, Barathi VA, Chaurasia SS, Wong TY, Kern TS (2012) Update on animal models of diabetic retinopathy: from molecular approaches to mice and higher mammals. Dis Model Mech 5:444-456. CrossRef Medline

Sasaki M, Ozawa Y, Kurihara T, Kubota S, Yuki K, Noda K, Kobayashi S,
Ishida S, Tsubota K (2010) Neurodegenerative influence of oxidative stress in the retina of a murine model of diabetes. Diabetologia 53:971979. CrossRef Medline

Schmittgen TD, Livak KJ (2008) Analyzing real-time PCR data by the comparative $\mathrm{C}(\mathrm{T})$ method. Nat Protoc 3:1101-1108. CrossRef Medline

Seki M, Tanaka T, Nawa H, Usui T, Fukuchi T, Ikeda K, Abe H, Takei N (2004) Involvement of brain-derived neurotrophic factor in early retinal neuropathy of streptozotocin-induced diabetes in rats: therapeutic potential of brain-derived neurotrophic factor for dopaminergic amacrine cells. Diabetes 53:2412-2419. CrossRef Medline

Shirao Y, Kawasaki K (1998) Electrical Responses from Diabetic Retina. Prog Retin Eye Res 17:59-76. CrossRef Medline

Thulé PM, Campbell AG, Kleinhenz DJ, Olson DE, Boutwell JJ, Sutliff RL, Hart CM (2006) Hepatic insulin gene therapy prevents deterioration of vascular function and improves adipocytokine profile in STZ-diabetic rats. Am J Physiol Endocrinol Metab 290:E114-E122. Medline

Tosini G, Baba K, Hwang CK, Iuvone PM (2012) Melatonin: an underappreciated player in retinal physiology and pathophysiology. Exp Eye Res 103:82-89. CrossRef Medline

Trulson ME, Himmel CD (1983) Decreased brain dopamine synthesis rate and increased $(3 \mathrm{H})$ spiroperidol binding in streptozotocin-diabetic rats. J Neurochem 40:1456-1459. CrossRef Medline

Turner PV, Albassam MA (2005) Susceptibility of rats to corneal lesions after injectable anesthesia. Comp Med 55:175-182. Medline

Villarroel M, Ciudin A, Hernández C, Simó R (2010) Neurodegeneration: An early event of diabetic retinopathy. World J Diabetes 1:57-64. CrossRef Medline

Witkovsky P (2004) Dopamine and retinal function. Doc Ophthalmol 108: 17-40. CrossRef Medline

Yamauchi T, Kashii S, Yasuyoshi H, Zhang S, Honda Y, Ujihara H, Akaike A (2003) Inhibition of glutamate-induced nitric oxide synthase activation by dopamine in cultured rat retinal neurons. Neurosci Lett 347:155-158. CrossRef Medline

Young ME, Wilson CR, Razeghi P, Guthrie PH, Taegtmeyer H (2002) Alterations of the circadian clock in the heart by streptozotocin-induced diabetes. J Mol Cell Cardiol 34:223-231. CrossRef Medline 